\title{
Atopic dermatitis and autoimmunity: the occurrence of autoantibodies and their association with disease severity
}

\author{
James Holmes ${ }^{1} \cdot$ Lucy C. Fairclough $^{1} \cdot \operatorname{lan}_{\text {Todd }^{1}}{ }^{\text {D }}$ \\ Received: 3 July 2018 / Revised: 5 December 2018 / Accepted: 9 February 2019 / Published online: 23 February 2019 \\ (C) The Author(s) 2019
}

\begin{abstract}
Atopic dermatitis (AD) is a widespread condition that appears to be increasing in prevalence and severity worldwide, yet the underlying mechanisms are not well understood. Recent research has identified various similarities between AD and autoimmune conditions, as well as indicating that there may be an association between AD and autoimmunity. This systematic review evaluates the association between $\mathrm{AD}$ and autoimmunity, as well as between severity of disease in AD and autoimmunity, with an emphasis on the associations with autoantibodies. MEDLINE (1946 to December 2017) and Embase (1974 to December 2017) databases were searched. Further relevant articles were retrieved from reference lists. Only studies measuring direct indicators of autoimmunity, in humans, were included. Qualitative analysis was carried out for all studies. In addition, quantitative analysis was used to evaluate prevalence of IgE autoantibodies and anti-nuclear antibodies (ANAs) in AD patients and control subjects. The Mantel-Haenszel method was used with a random-effects model. 28 studies assessed the occurrence of autoantibodies in $\mathrm{AD}$ patients and 16 studies were used to evaluate association between disease severity and autoantibodies. Pooled analysis from 14 studies, involving 986 AD patients and 441 control subjects, showed that IgE autoantibodies were significantly more prevalent in patients with $\mathrm{AD}(P<0.00001)$ than control subjects. Similar analysis was carried out for ANAs, with eight studies that involved 1045 AD patients and 1273 control subjects. ANAs were significantly more prevalent in patients with $\mathrm{AD}(P=0.003)$. This quantitative analysis supported an association between $\mathrm{AD}$ and IgE autoantibodies, as well as between AD and ANAs. There was insufficient data to make similar conclusions for other indicators of autoimmunity. The weight of evidence also suggests an association between IgE autoantibodies and disease severity. There was insufficient evidence to make this link for other indicators of autoimmunity.
\end{abstract}

Keywords Atopic dermatitis $\cdot$ Autoimmunity $\cdot$ Autoantibody $\cdot \operatorname{IgE} \cdot \operatorname{IgG} \cdot \operatorname{IgA} \cdot$ Anti-nuclear autoantibodies

\section{Introduction}

The term Atopic Dermatitis (AD) was first used by Wise and Sulzberger in 1933 [1]. The World Allergy Organisation defines eczema (also known as atopic eczema dermatitis syndrome (AEDS) and as AD throughout this review) as 'an inflammatory, chronically relapsing, non-contagious and extremely pruritic skin disease' [2].

Prevalence of AD worldwide is high, with $7.9 \%$ of 6-7 years presenting with the condition in the ISAAC Phase 3 study [3]. AD appears to be increasing in prevalence

Ian Todd

ian.todd@nottingham.ac.uk

1 School of Life Sciences, University of Nottingham, Life Sciences Building, University Park, Nottingham NG7 2RD, UK globally, with centres reporting increases in self-reported $\mathrm{AD}$ and severe $\mathrm{AD}$ [3]. There was significant variance in the prevalence of $\mathrm{AD}$ between centres, both within and across regions, which has been attributed, in part, to environmental differences [4]. The increasing prevalence and severity of $\mathrm{AD}$ makes it essential to understand the underlying mechanisms of the disease, enabling more effective future treatments.

$\mathrm{AD}$ is traditionally thought of as an allergic condition with extrinsic allergens driving the immune response. The discovery of a deficiency in the stratum corneum caused by filaggrin gene mutations supports this, as impaired skin barrier function allows for allergens to infiltrate the body, inducing an immune response [5]. AD patients with these mutations are more likely to have persistent, severe, allergen-driven symptoms, but some patients continue to suffer from $\mathrm{AD}$ despite removal of stimuli such as dust mites or 
pollen [6]. Overall, as many as two-thirds of AD patients demonstrate 'no measurable allergen-specific IgE antibody sensitization' [7].

One hypothesis as to why chronic inflammation persists, despite removal of environmental allergens, is infection by Staphylococcus aureus. S. aureus colonization was found in more than $90 \%$ of patients and was found to correlate significantly with severity [8]. S. aureus has a contribution to most $\mathrm{AD}$ lesions, both by worsening inflammation through direct action of toxins and by increasing production of IgE antibodies [9]. It would follow that other skin based microorganisms, such as the fungus Malassezia sympodialis, could also cause this type of exacerbation, but this does not account for patients that suffer AD lesions without allergic sensitisation.

Despite the traditional understanding of $\mathrm{AD}$, there has been evidence to suggest there might be an autoimmune component to the disease. Disease progression in $\mathrm{AD}$ is similar to that in known autoimmune conditions, involving periods of relapse and remission. Furthermore, a significant association has been found between $\mathrm{AD}$ and 11 autoimmune conditions, as well as the fact that $\mathrm{AD}$ patients are more likely to present with 'multiple autoimmune comorbidities' [10]. Finally, immediate skin reactions to some human proteins indicate that, for some patients, IgE autoantibodies are produced [11] which could contribute to disease progression. Researchers have also recently claimed that they have proven that 'atopic dermatitis ... is an immune-driven (autoimmune) disease' [12] by treating AD with Dupilumab. This blocked IL-4 and IL-13 [13], to prevent Th2 cytokines from incorrectly targeting autologous tissues.

\section{Methods}

This systematic review investigates the link between $\mathrm{AD}$ and autoimmunity (with an emphasis on autoantibodies), providing an update to, and widening of scope of, a systematic review from 6 years earlier [14]. The present review evaluates the strength of the link between $\mathrm{AD}$ and autoantibodies, and whether there is an association between $\mathrm{AD}$ severity and autoantibodies.

\section{Identification of relevant studies}

Two modifications were made to the search strategy employed in 2012 by Tang et al. [14]: 'autologous' was added as a search term and the Embase database was searched in addition to MEDLINE. These alterations ensured the search strategy reflected current terminology and that as many relevant papers as possible were found.

The search terms were as follows:
1. exp Dermatitis, Atopic/

2. atopic dermatitis.mp.

3. dermatitis atopic.mp.

4. exp Eczema/

5. childhood eczema.mp.

6. infantile eczema.mp.

7. 1 or 2 or 3 or 4 or 5 or 6

8. exp Autoimmunity/

9. exp Autoantigens/

10. Autoallerg\$.mp.

11. autoreactivity.mp.

12. Profilins/

13. ribosomal P2.mp.

14. exp Thioredoxins/

15. exp immunoglobulin $\mathrm{G} /$

16. exp immunoglobulin E/

17. superoxide Dismutase/

18. autoantibod\$.mp.

19. self-antigen.mp.

20. self-react\$.mp.

21. autologous.mp.

22. 8 or 9 or 10 or 11 or 12 or 13 or 14 or 15 or 16 or 17 or 18 or 19 or 20 or 21

23. 7 and 22

24. limit 23 to (male and female and humans and humans)

Database searching was carried out during October to December 2017.

The PRISMA diagram [15] in Fig. 1 gives an overview of the number of papers at each stage of the literature search. Titles and abstracts from this search were checked, yielding 165 papers that warranted full-text analysis. These were scanned in full, with 28 studies providing evidence relating to an association between AD and autoantibodies, and 16

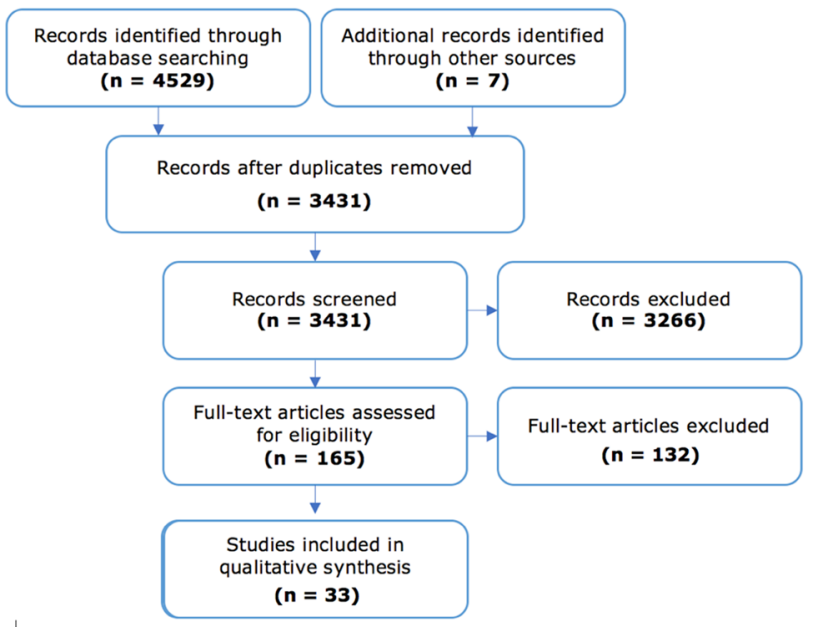

Fig. 1 PRISMA diagram (adapted from [16]) 


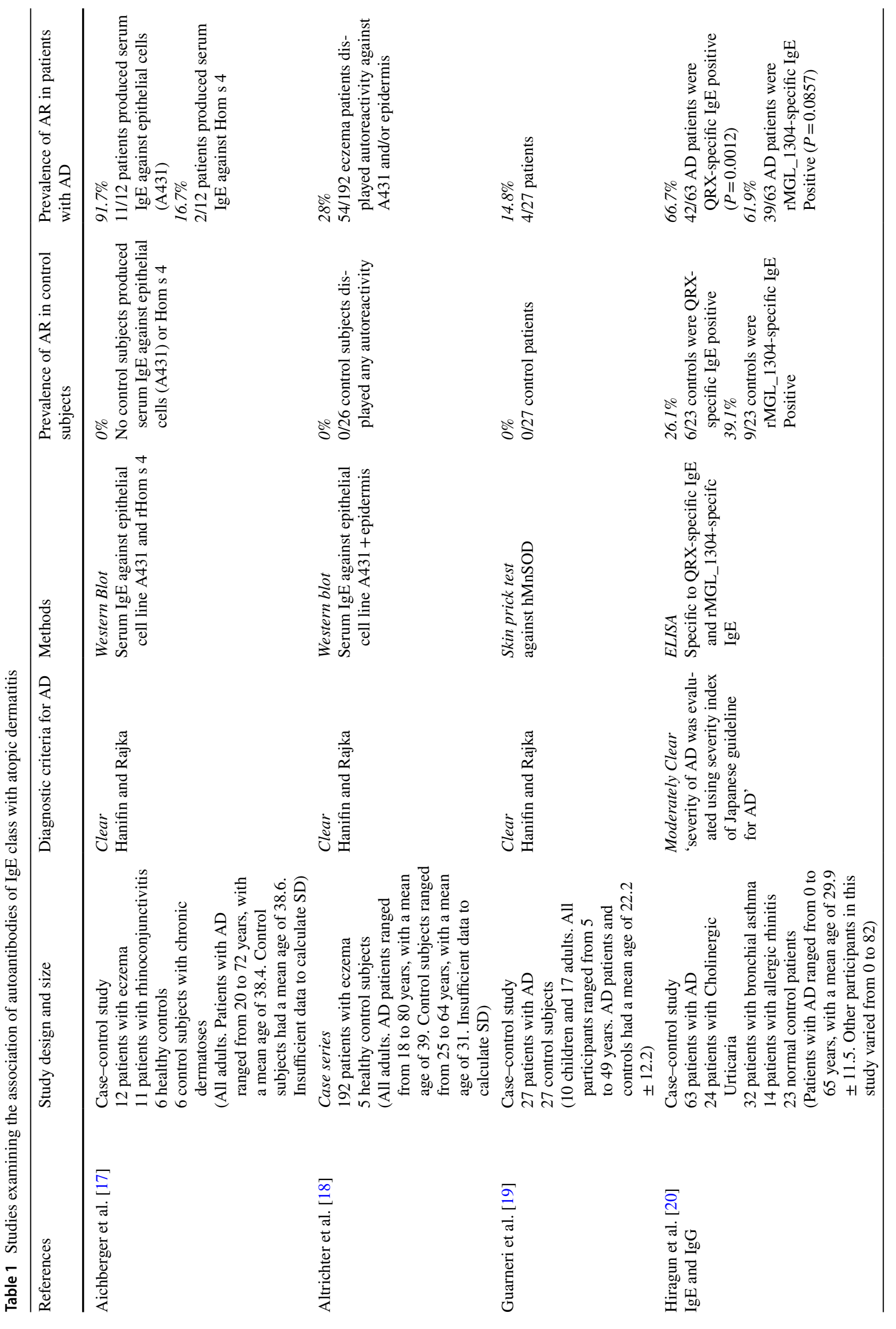




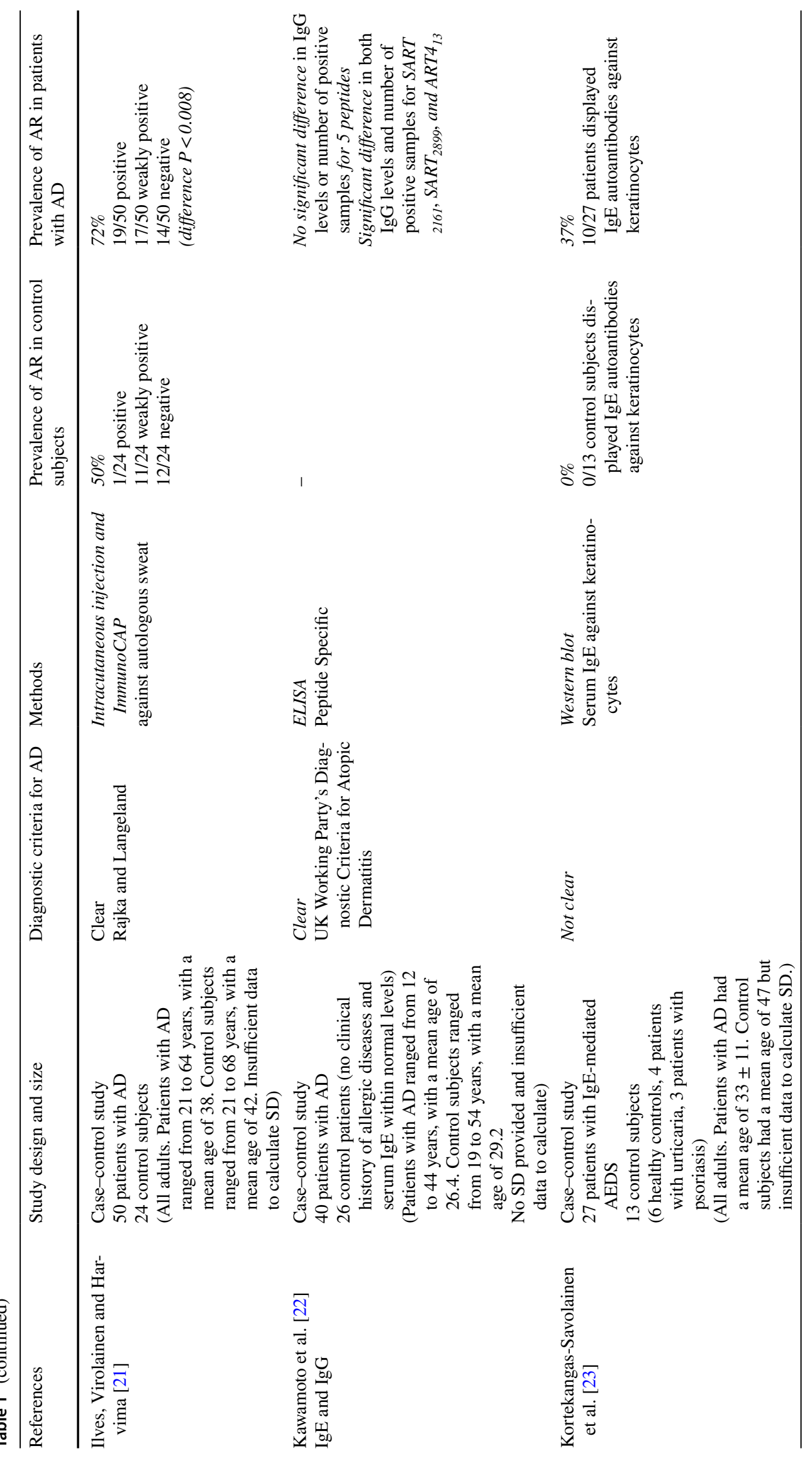




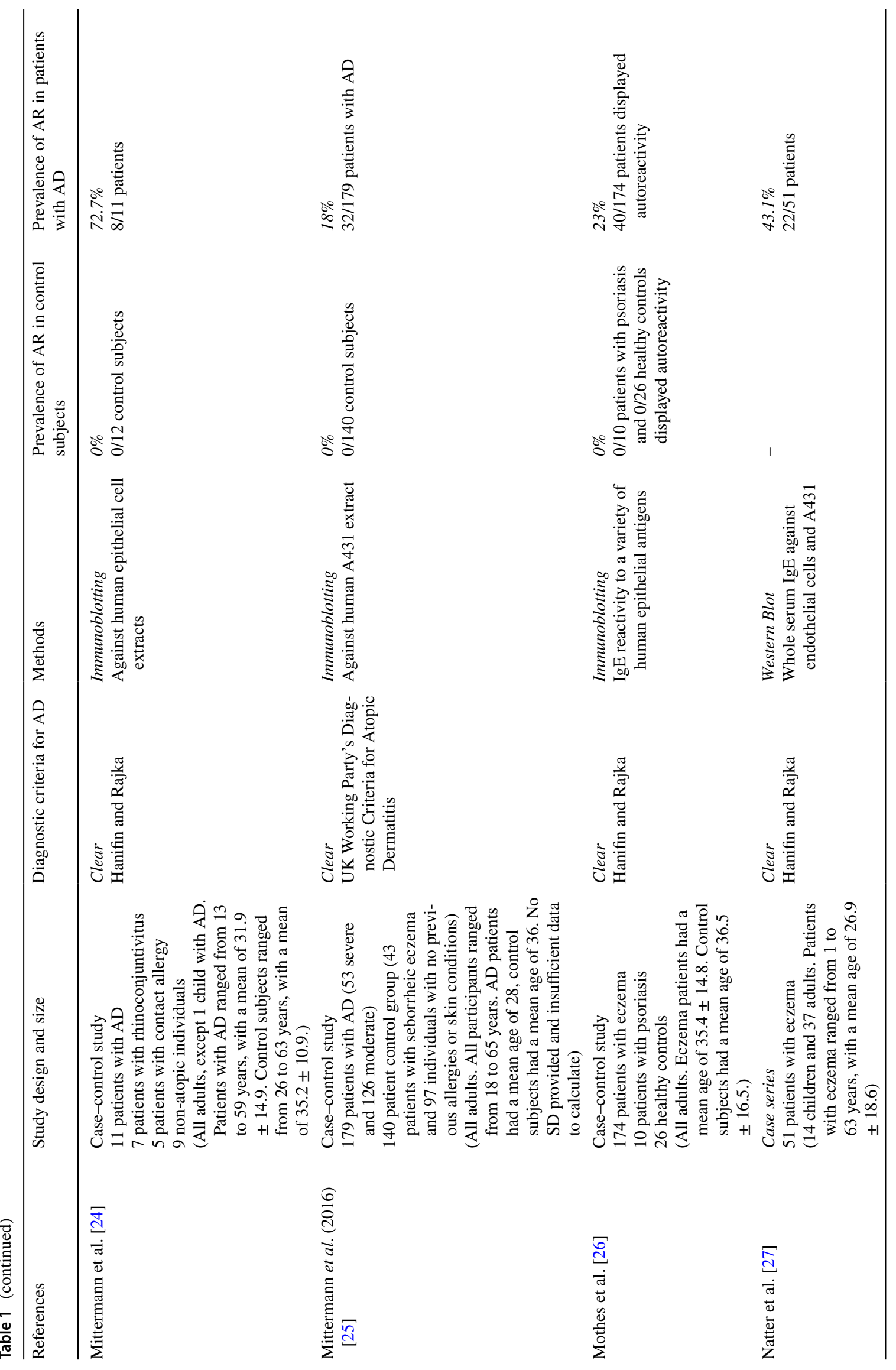




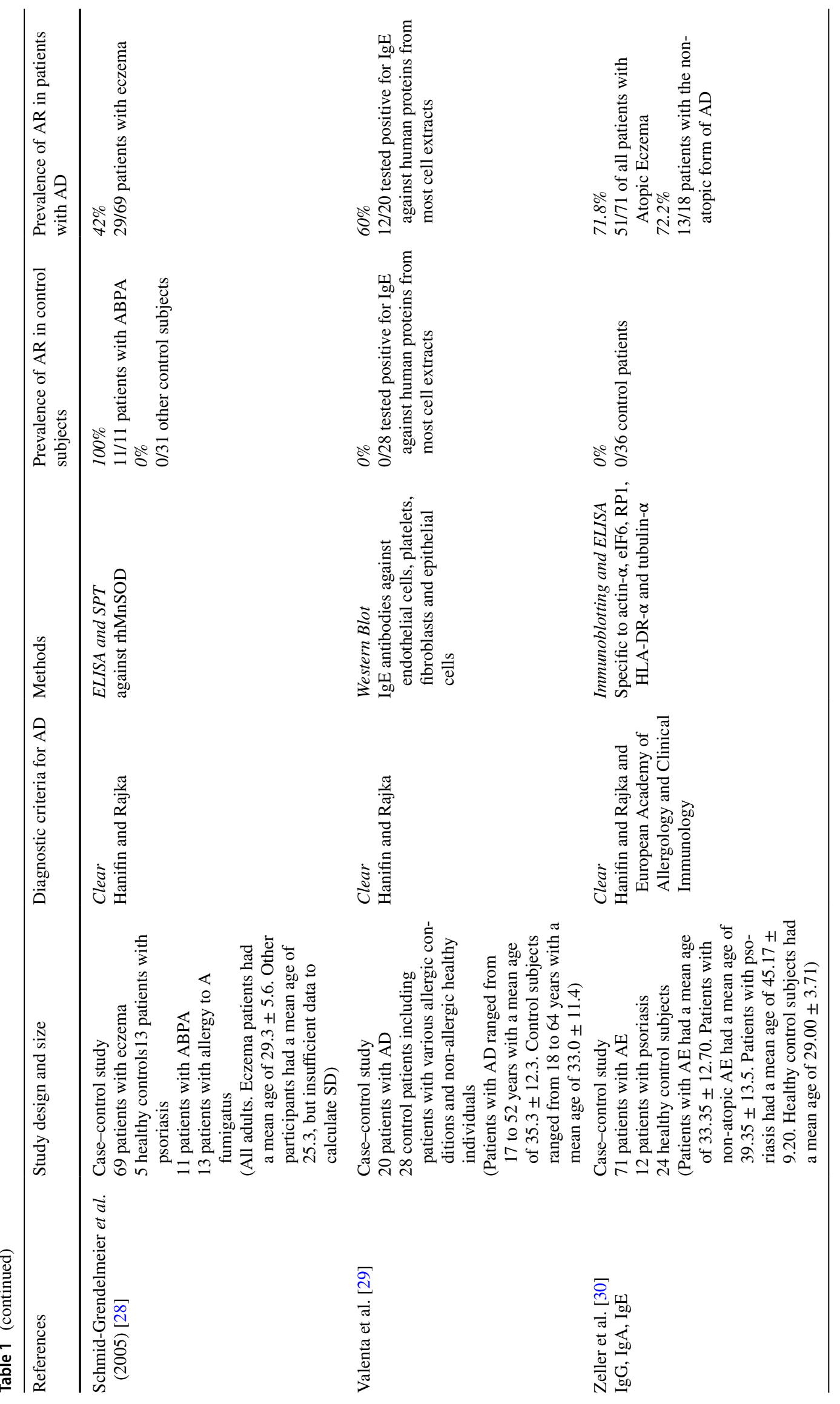


that evaluated severity of $\mathrm{AD}$ in relation with the occurrence of autoantibodies. During this full-text analysis, the reference sections of papers were checked to identify relevant papers that had not appeared in the search results. Most papers excluded at this point were conference proceedings or included results not linked to autoimmunity and AD.

\section{Inclusion criteria}

\section{Language}

All literatures evaluated in this systematic review were in English (including papers that had already been translated in to English).

\section{Types of studies}

Due to the wide range of study designs present in the literature, all the types of study were included. The main types of study evaluated were case-control studies, case series, and individual case reports.

\section{Types of participants}

This systematic review evaluated all studies involving human participants, irrespective of age or gender. Studies varied in the age ranges of the participants (details in Tables 1, 3, 4, $5,7)$ : most included adults only or a mixture of children and adults, whereas a few studies included children only. However, there was no apparent effect of participants' age on the relationship between autoreactivity and AD (Table 2) or severity of AD (Table 6). All the literature was included regardless of whether they had clear criteria for selecting patients with AD. These criteria have been noted for all studies in appendices, but have only been referred to in the main text when these criteria are unclear or missing.

\section{Types of publication}

In this systematic review, all papers published in journals were included, with the exception of reviews and editorials. Letters to journals were included, as they were a key source of smaller studies. Grey literature was not included.

\section{Outcome measures}

The papers evaluated in the systematic review were heterogeneous in both study design and outcome measures. The only restriction was that studies had to provide direct evidence of autoantibodies. When evaluating the association between autoantibodies and $\mathrm{AD}$, any tests that indicated autoantibodies, for example, ELISA and skin prick tests (SPTs), were included. When evaluating the association between severity of $\mathrm{AD}$ and autoantibodies, all measures of severity were included. The most common measures of severity were SCORAD (SCORing Atopic Dermatitis) [44] and Rajka and Langeland [45] systems, although some authors used other assessments of severity.

\section{Statistical analysis}

Where appropriate, a quantitative analysis was carried out using Review Manager 5.3 [46]. The Mantel-Haenszel method was used with a random-effects model to account for the variation in study design and resultant difference in effect size.

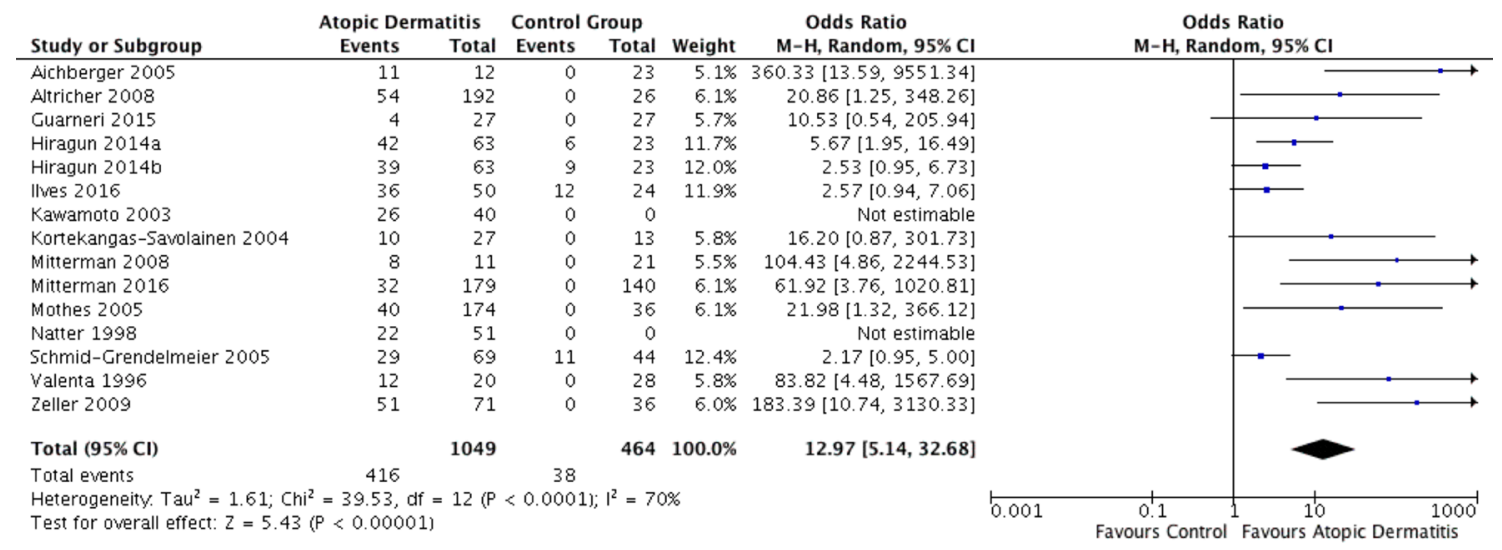

Fig. 2 Forest plot showing data from all studies into IgE antibodies. 'Events' are instances of autoimmunity, and 'total' refers to the total number of people in that group of a study 


\section{Results}

\section{Association of autoantibodies with atopic dermatitis}

28 papers were identified that fulfilled the inclusion criteria and were relevant to this part of the review. The main indicators of autoimmunity investigated were specific IgE and $\operatorname{IgG}$ antibodies, as well as IgG ANAs.

\section{Autoantibodies of IgE class}

14 studies investigated the presence of specific $\operatorname{IgE}$ autoantibodies in patients with $\mathrm{AD}$; the details of these studies are summarised in Table 1 (in alphabetical order of the first authors). Twelve were case-control studies, of which 11 indicated that certain $\operatorname{IgE}$ autoantibodies were significantly more common in patients with $\mathrm{AD}$. The study quality was generally good, with well-described protocols, often using western blot, ELISA or SPT techniques, and robustly defined criteria for selection of AD patients in most cases. Most studies evaluated the presence of $\operatorname{IgE}$ autoantigens to epithelial cells, epithelial cell extracts, and other proposed autoantigens associated with the skin. Furthermore, the control groups were comprised predominantly of healthy individuals which makes comparison between, and pooling of, individual studies much easier and more useful. This meant an analysis could be carried out on the combined data, which established an odds ratio of 12.97 (with $95 \%$ confidence limits of 5.14-32.68) and $P<0.00001$, indicating that $\operatorname{IgE}$ autoantibodies are significantly more likely to be identified in patients with AD compared to the control groups (Fig. 2). This effect seemed to be uniform across all tested antigens, although the majority of evidence concerns specific antibodies to epithelial cell extracts. A qualitative analysis of the studies also indicated that all but one (13/14) concluded that
Table 2 Association of autoantibodies with atopic dermatitis

\begin{tabular}{|c|c|c|}
\hline Marker of autoimmunity & $\begin{array}{l}\text { Papers that indicate autoreactivity is } \\
\text { more common in patients with } \mathrm{AD}\end{array}$ & $\begin{array}{l}\text { Papers that do not indicate autoreactiv- } \\
\text { ity is more common in patients with } \mathrm{AD}\end{array}$ \\
\hline IgE autoantibodies & $\begin{array}{l}\mathbf{1 3} \\
\text { Aichberger et al. [17] } \\
\text { Altrichter et al. [18] } \\
\text { Guarneri et al. [19] } \\
\text { Hiragun et al. (for QRX) [20] } \\
\text { Ilves, Virolainen and Harvima [21]* } \\
\text { Kortekangas-Savolainen et al. [23] } \\
\text { Mittermann et al. [24, 25] } \\
\text { Mothes et al. [26] } \\
\text { Natter et al. [27] } \\
\text { Schmid-Grendelmeier et al. [28] } \\
\text { Valenta et al. [29] } \\
\text { Zeller et al. [30] }\end{array}$ & $\begin{array}{l}\mathbf{2} \\
\text { Hiragun et al. (for rMGL_1304) }[20]^{\dagger} \\
\text { Kawamoto et al. }[22]^{\S}\end{array}$ \\
\hline IgG autoantibodies & $\begin{array}{l}\mathbf{4} \\
\text { Bergman et al. [31]* (for CCL-3) } \\
\text { Neuber et al. [32]* } \\
\text { Ochs et al. [33] } \\
\text { Szakos et al. [34]* }\end{array}$ & 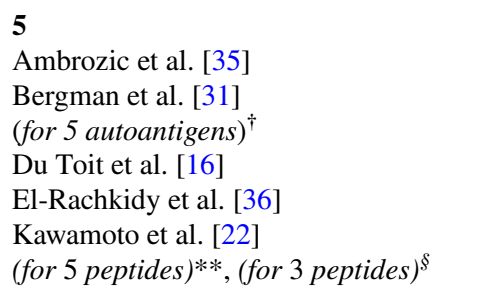 \\
\hline IgA autoantibodies & $\mathbf{0}$ & $\begin{array}{l}\mathbf{1} \\
\text { Ress et al. [37] }\end{array}$ \\
\hline ANAs & $\begin{array}{l}7 \\
\text { Dhar, Kanwar and Deodhar [38] } \\
\text { Higashi et al. [39] } \\
\text { Ochs et al. [33] } \\
\text { Ohkouchi et al. [40]* } \\
\text { Szakos et al. [34] } \\
\text { Tada et al. [41] } \\
\text { Taniguchi et al. [42] }\end{array}$ & $\begin{array}{l}\mathbf{1} \\
\text { Ress et al. }[43]^{\dagger}\end{array}$ \\
\hline
\end{tabular}

*Differences were statistically significant

$\dagger$ Differences were not statistically significant

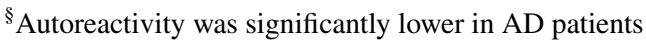




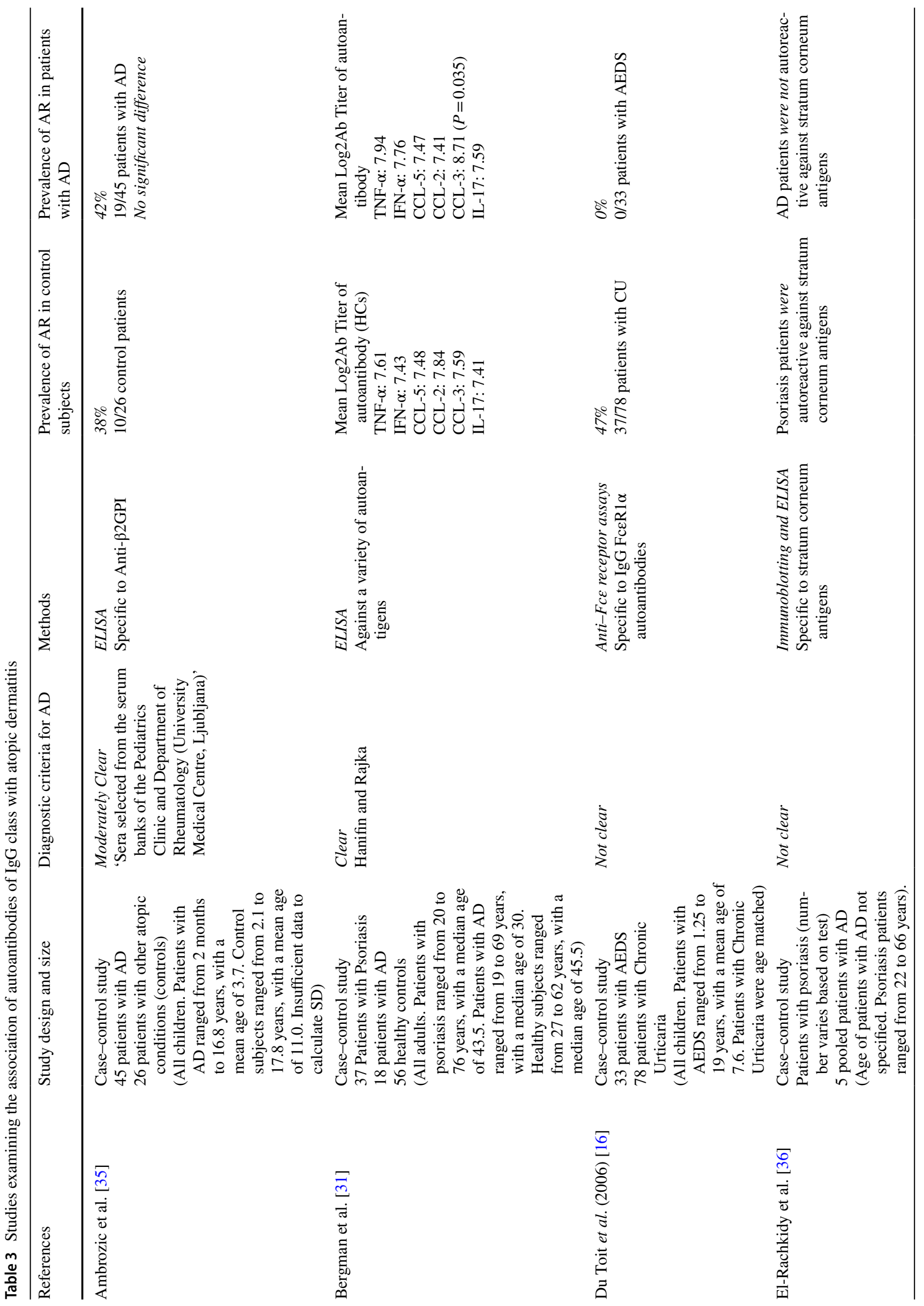




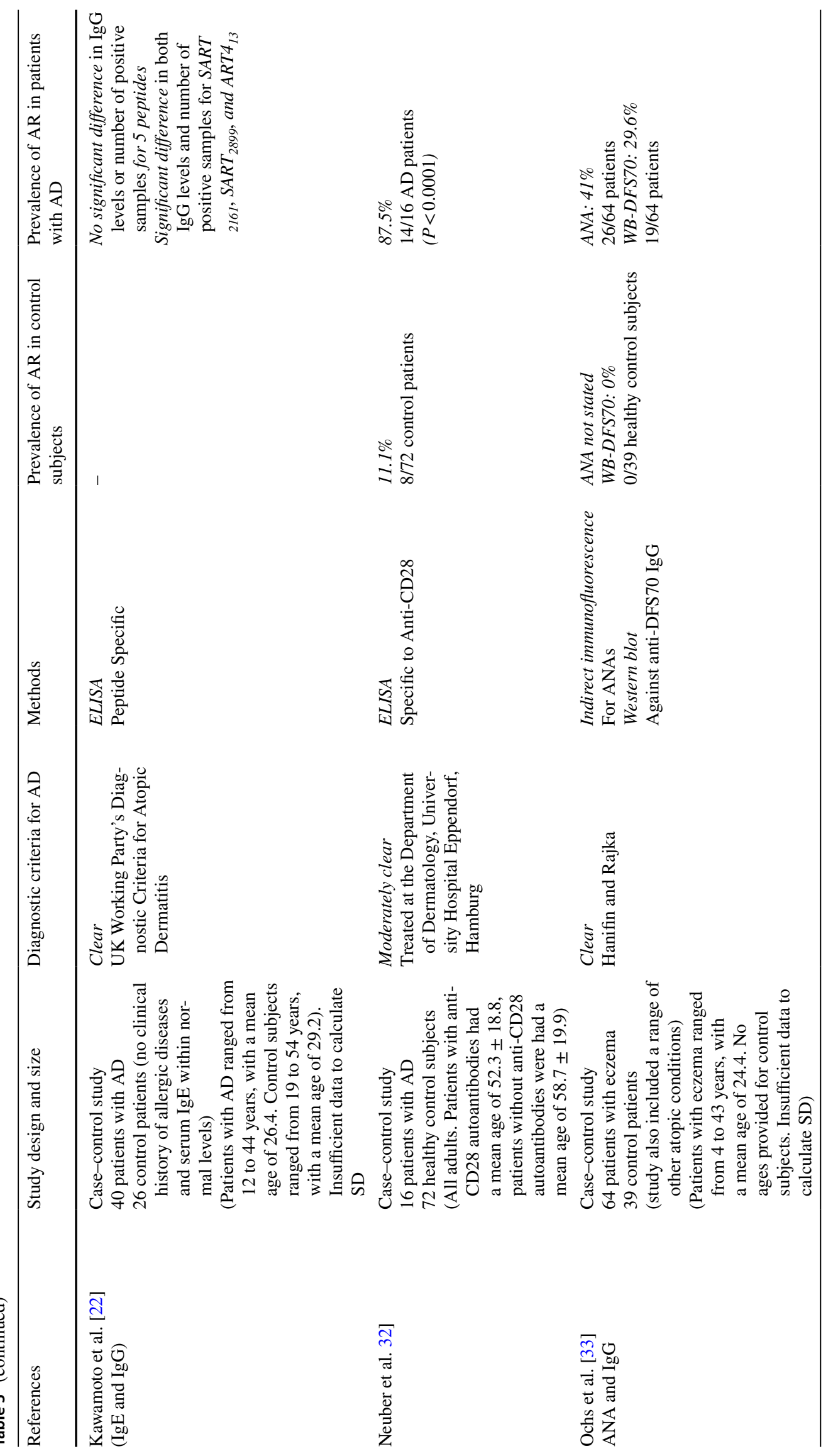




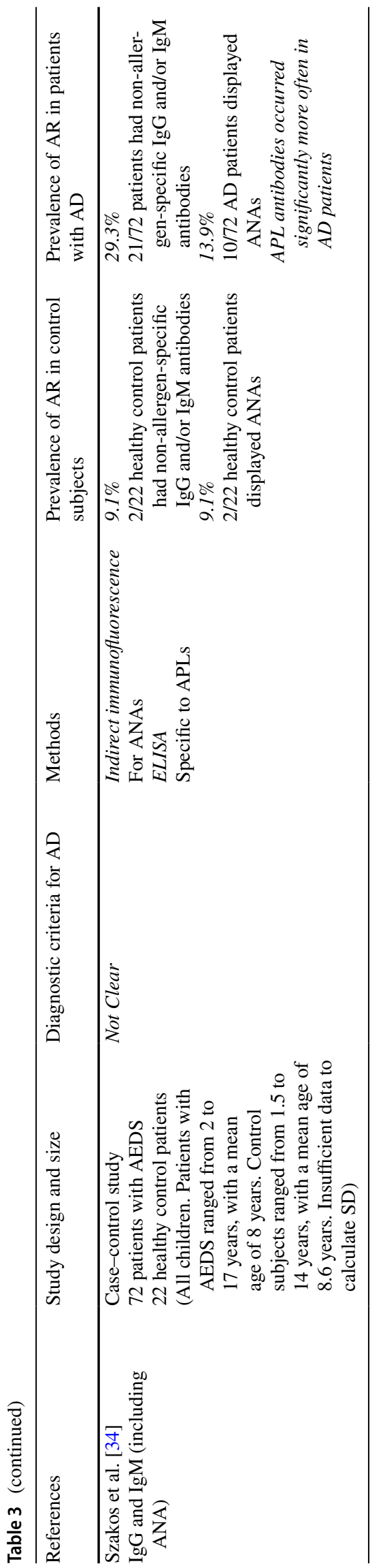

IgE class autoantibodies are more common in AD patients than controls (Table 2).

\section{Autoantibodies of IgG class}

Eight studies investigated the presence of specific $\operatorname{IgG}$ autoantibodies in AD (Table 3). However, it was not possible to carry out a quantitative analysis: whilst the studies predominantly used ELISA techniques, the study design was too varied for a pooled analysis. Some studies only compared $\mathrm{AD}$ patients against patients with other conditions, for example psoriasis, whilst others only provided mean titres. Furthermore, only three of the studies had clear definitions for AD diagnosis. Because of the more variable study design, it was more appropriate to carry out a qualitative review. Levels of IgG autoantibodies specific to SART2 ${ }_{161}$, SART2$_{899}$, ART4$_{13}$ [22], CCL3 [31] and CD28 [32], as well as APL antibodies [34] were significantly higher than in their respective control groups, but levels of autoantibodies specific to $\beta_{2}$ GPI [35], TNF- $\alpha$, IFN- $\alpha$, CCL-5, CCL-2, IL-17 [31], and five other peptides [22] were not significantly higher. Autoantibodies against DFS70 [33] and $\mathrm{Fc}_{\varepsilon} \mathrm{R} 1_{\alpha}$ autoantibodies [16] were more commonly identified in $\mathrm{AD}$ patients than the respective control groups, but no statistical analysis was carried out. Finally, AD patients were found not to display an autoreactive response to stratum corneum antigens, but psoriasis patients did (although no statistical analysis was carried out). Overall, there is no clear picture as to the presence of IgG autoantibodies in AD patients (Table 2). The mixed results, combined with more variable study techniques and less clarity with respect to inclusion criteria, means that more research is required into the relationship between $\mathrm{AD}$ and $\mathrm{IgG}$ autoantibodies.

\section{Autoantibodies of IgA class}

Only one study solely investigated IgA autoantibodies in AD: Ress et al. [37] carried out a large case-control study, comprising 297 patients with $\mathrm{AD}$ and 52 healthy control subjects. ELISA techniques were used to determine the presence of IgA-anti-transglutaminase 1 (anti-TG1) and IgA-anti-transglutaminase 3 (anti-TG3) in the control group and AD group. However, this study did not indicate an association between IgA autoantibodies and AD (Table 2), but there are insufficient studies to draw a clear conclusion. 


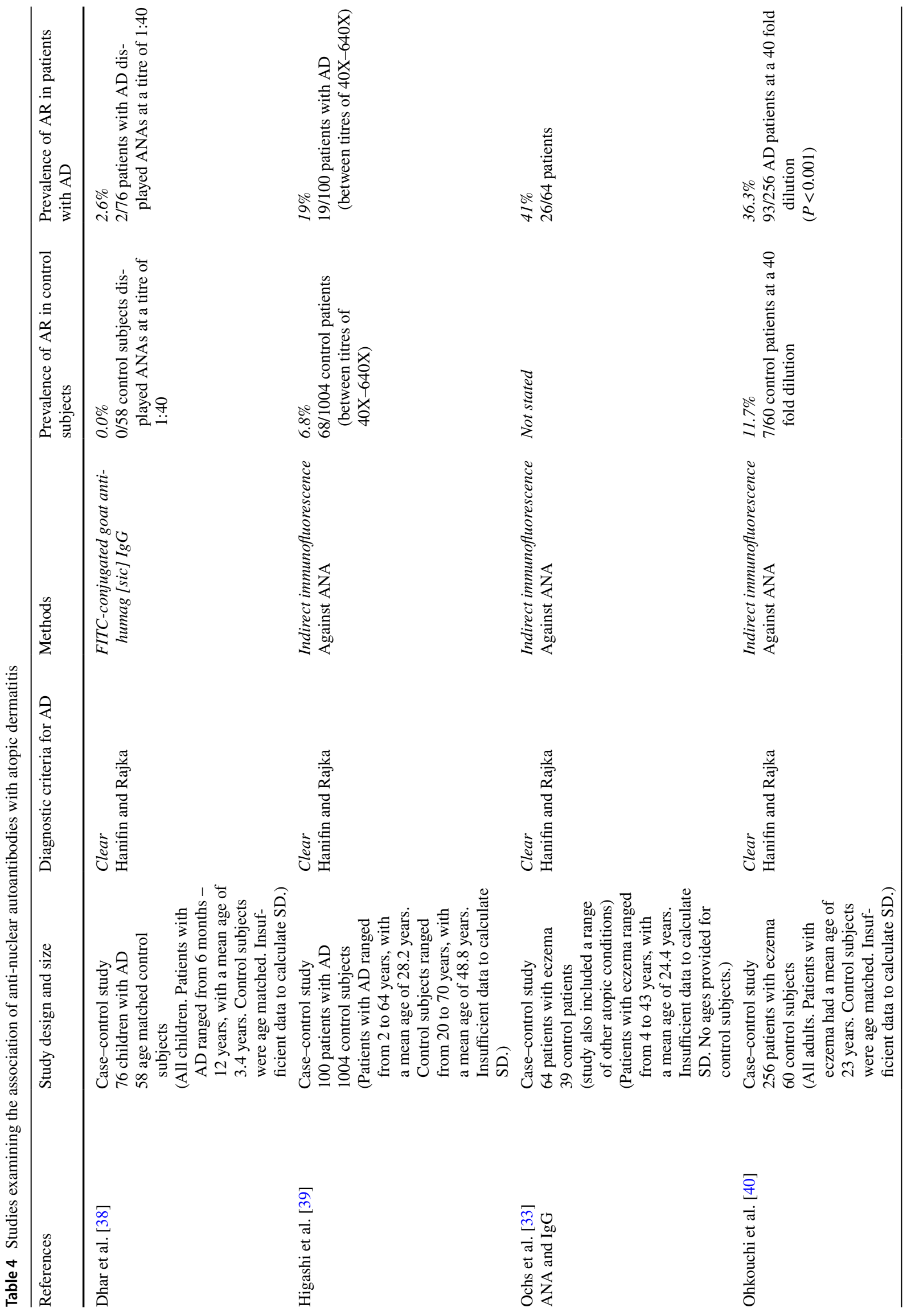




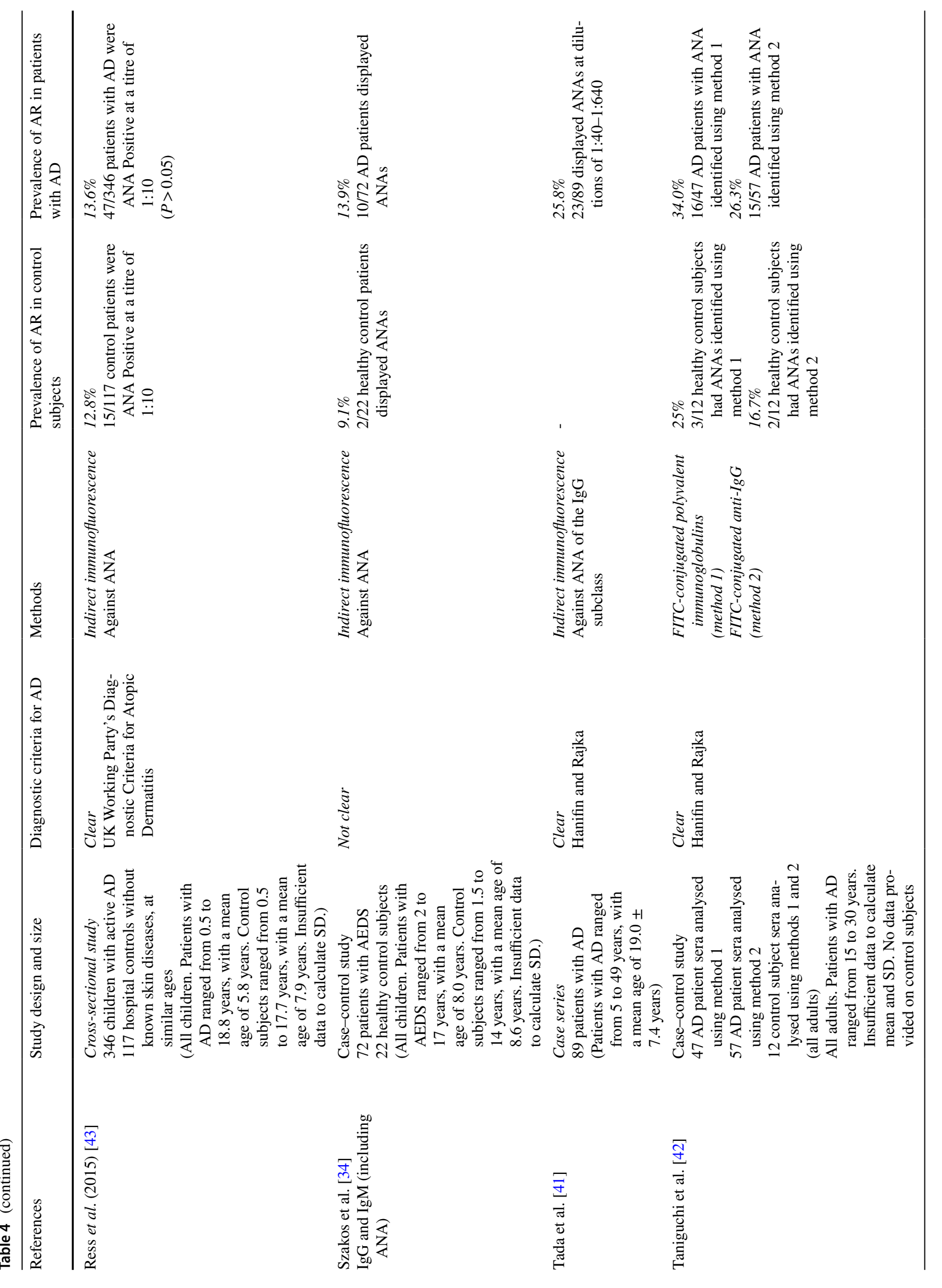




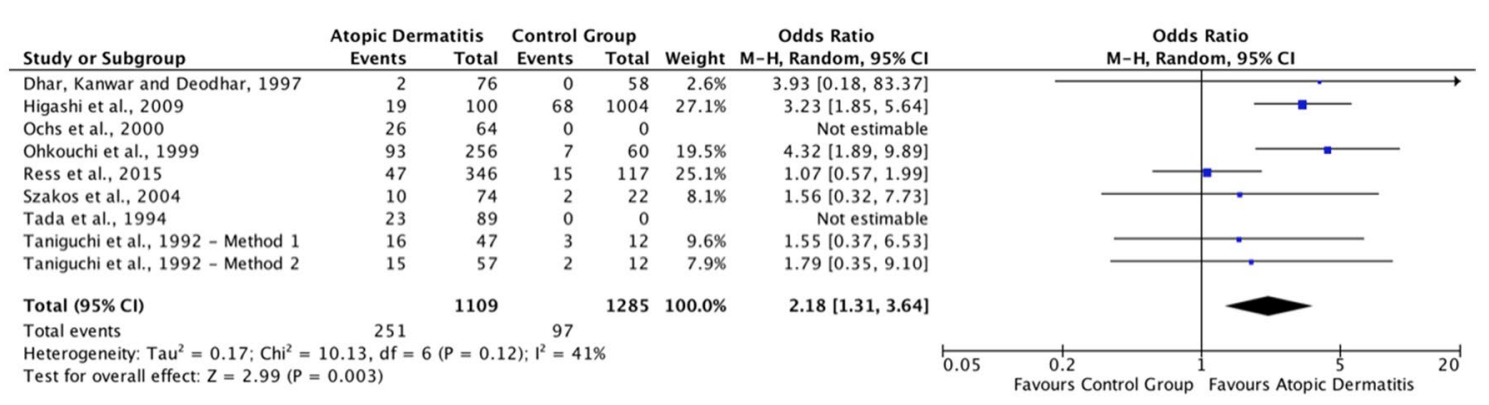

N.B. 'Ochs et al., 2000 ' - this study did not indicate the number of control subjects that displayed auto-reactivity. For this reason, although there were 39 control subjects, these were excluded from the forest plot.

Fig. 3 Forest plot showing data from all studies into ANAs. 'Events' are instances of autoimmunity, 'Total' refers to the total number of people in that group of a study

\section{Anti-nuclear autoantibodies}

Eight studies investigated ANAs in AD (Table 4), with two of these including ANAs as part of a wider study. Six of the eight were case-control studies. Most of these papers applied clear, commonly used definitions of $\mathrm{AD}$ and most used well-described methods-particularly indirect immunofluorescence-to identify ANAs. Seven of the eight papers indicate that ANAs occurred more commonly in patients with AD than in the control subjects (Table 2). Furthermore, the pooling of data showed that patients with $\mathrm{AD}$ have a significantly higher frequency of ANAs than the control subjects with an odds ratio of 2.18 (95\% confidence intervals $1.31-3.64)$ and $P=0.003$ (Fig. 3).

\section{Association of autoantibodies with severity of atopic dermatitis}

The second part of this systematic review considers whether there is an association between severity of disease in patients with AD and the presence of an autoimmune response. From the papers identified using the search strategy, 16 papers evaluated the presence of autoimmunity in combination with disease severity. 13 papers provide evidence of the relationship between IgE autoantibodies and disease severity (Tables 5, 6), and two provide research relating to ANAs (Table 6). The final paper investigated ANAs, APL antibodies, and ACL antibodies and their relationship with severity (Table 6).

Two main methods of assessing severity were used, SCORAD [44] and Rajka and Langeland [45] scores, although some researchers used other measures of severity. SCORAD was developed as a standardised method to assess severity of AD that could be used in outpatient clinics. It relies on three components: intensity (responsible for $60 \%$ of the total score), extent and subjective symptoms (each responsible $\approx 20 \%$ of the score). Rajka and Langeland also put forward a simple scoring index for $\mathrm{AD}$ using three parameters, each scored out of 3: extent, course (how much remission in a year) and intensity (scored according to how much it impacts sleep). The sum of these scores is calculated, with $3-4$ being defined as mild, $4.5-7.5$ being moderate, and $8-9$ being severe.

It is difficult to produce pooled data for the studies assessing a link between IgE autoantibodies and severity of $\mathrm{AD}$ due to wide variation in the measures of severity and outcome measures but, as shown in Table 6; the weight of evidence indicates that there is an association between the frequency of IgE autoantibodies and disease severity in AD. Furthermore, two studies $[48,50]$ looked at individual patients over time, assessed levels of $\operatorname{IgE}$ autoantibodies and SCORAD throughout treatment, and established a temporal link between SCORAD and IgE autoantibodies. Whilst it is impossible to determine from these studies whether the decrease in IgE autoreactivity as severity of disease declines is a separate response to the cyclosporine A treatment, an unrelated biomarker resulting from a decrease in disease severity, or indeed the cause of the reduced severity, it provides strong support for a link between AD disease severity and autoimmunity. This association did not seem to be present with respect to ANAs, as neither study that looked exclusively at ANAs demonstrated a significant association (Table 6), but more studies are required to reach a definitive conclusion. Szakos et al. [34] also indicated that there was no significant difference in disease severity in patients that displayed ANAs, ACL, APL or a combination of ANAs and APL (Table 6). Overall, the available evidence indicates that severity of $\mathrm{AD}$ is associated with autoimmunity, but that this response might be limited to IgE-mediated 


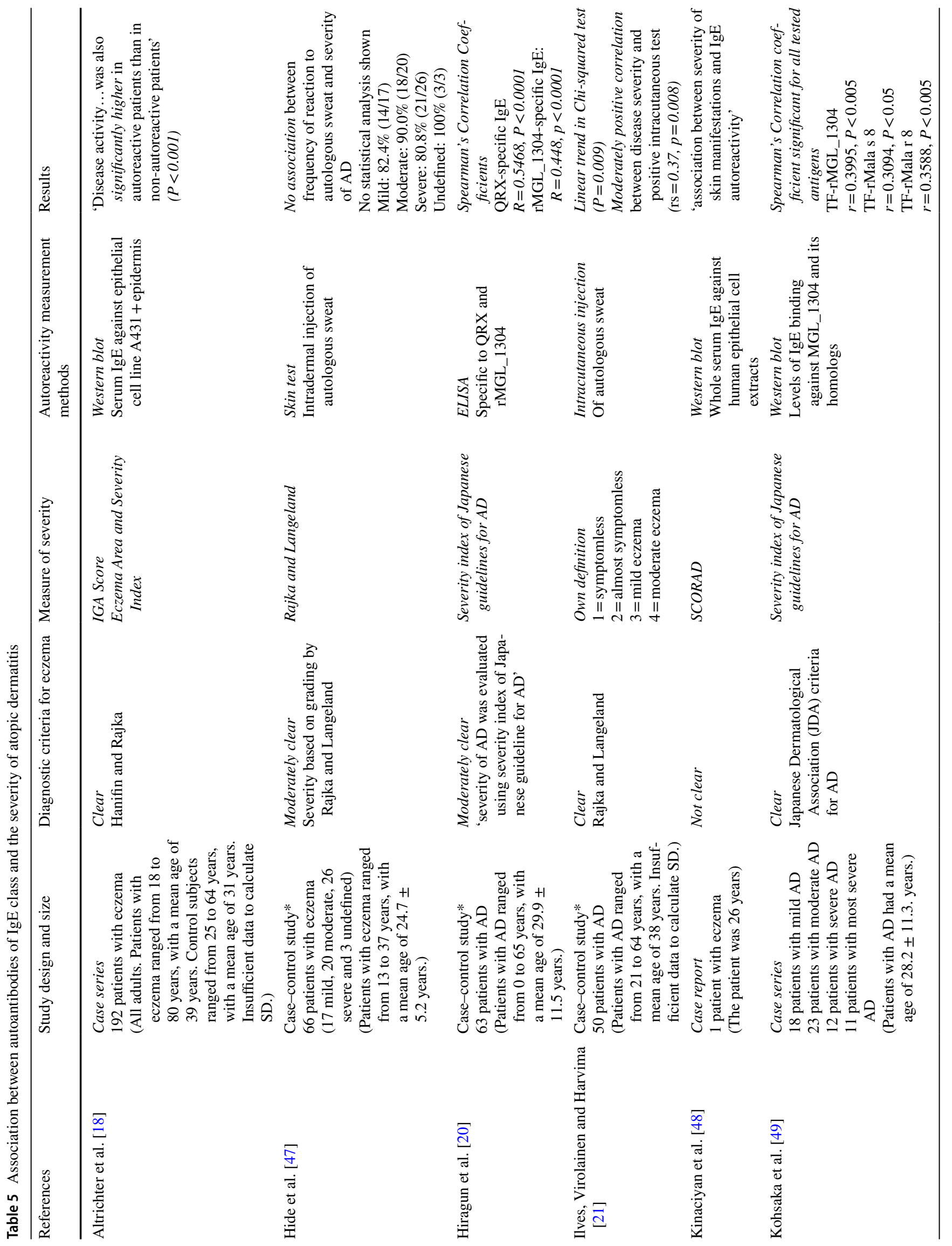




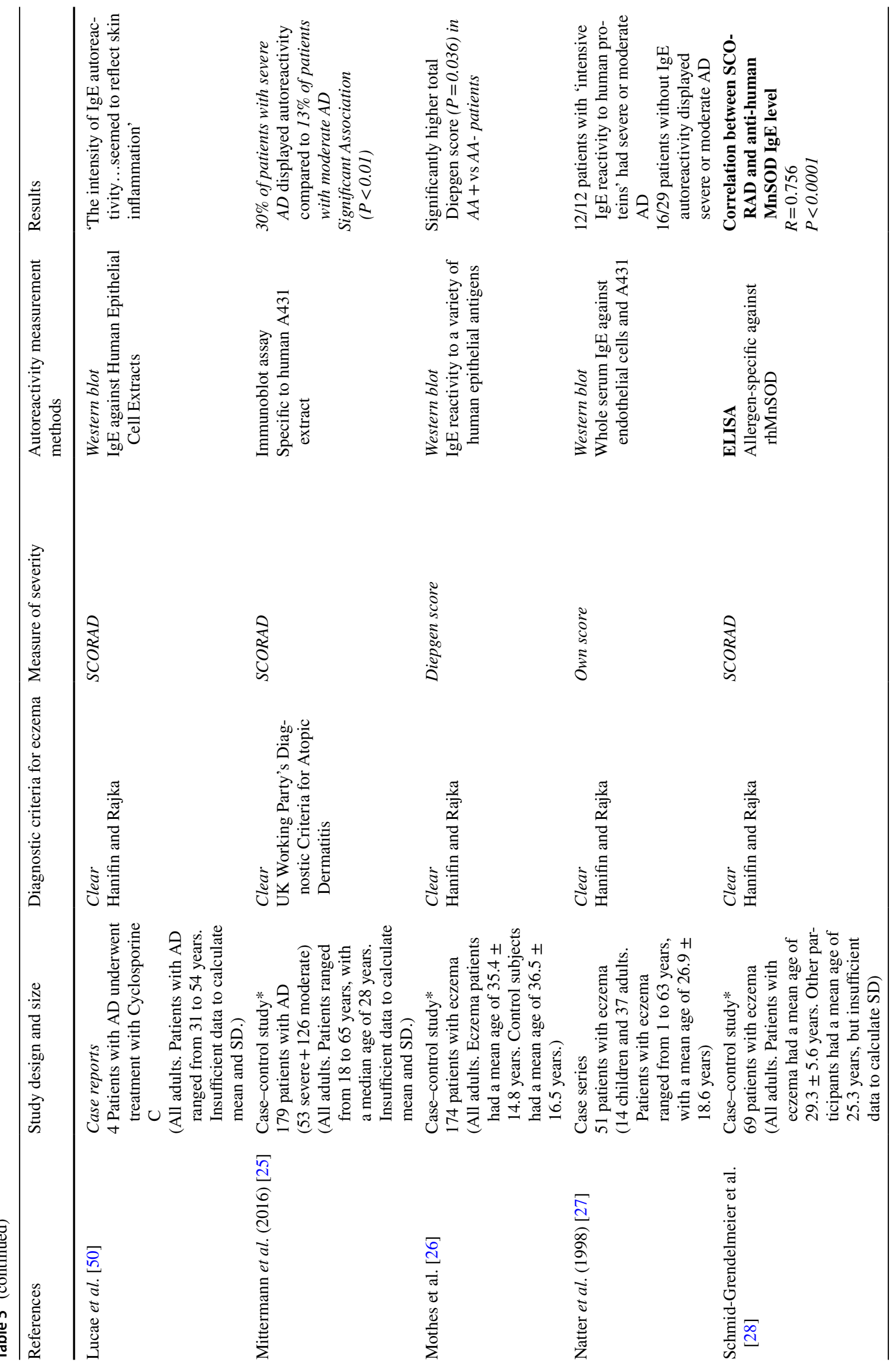




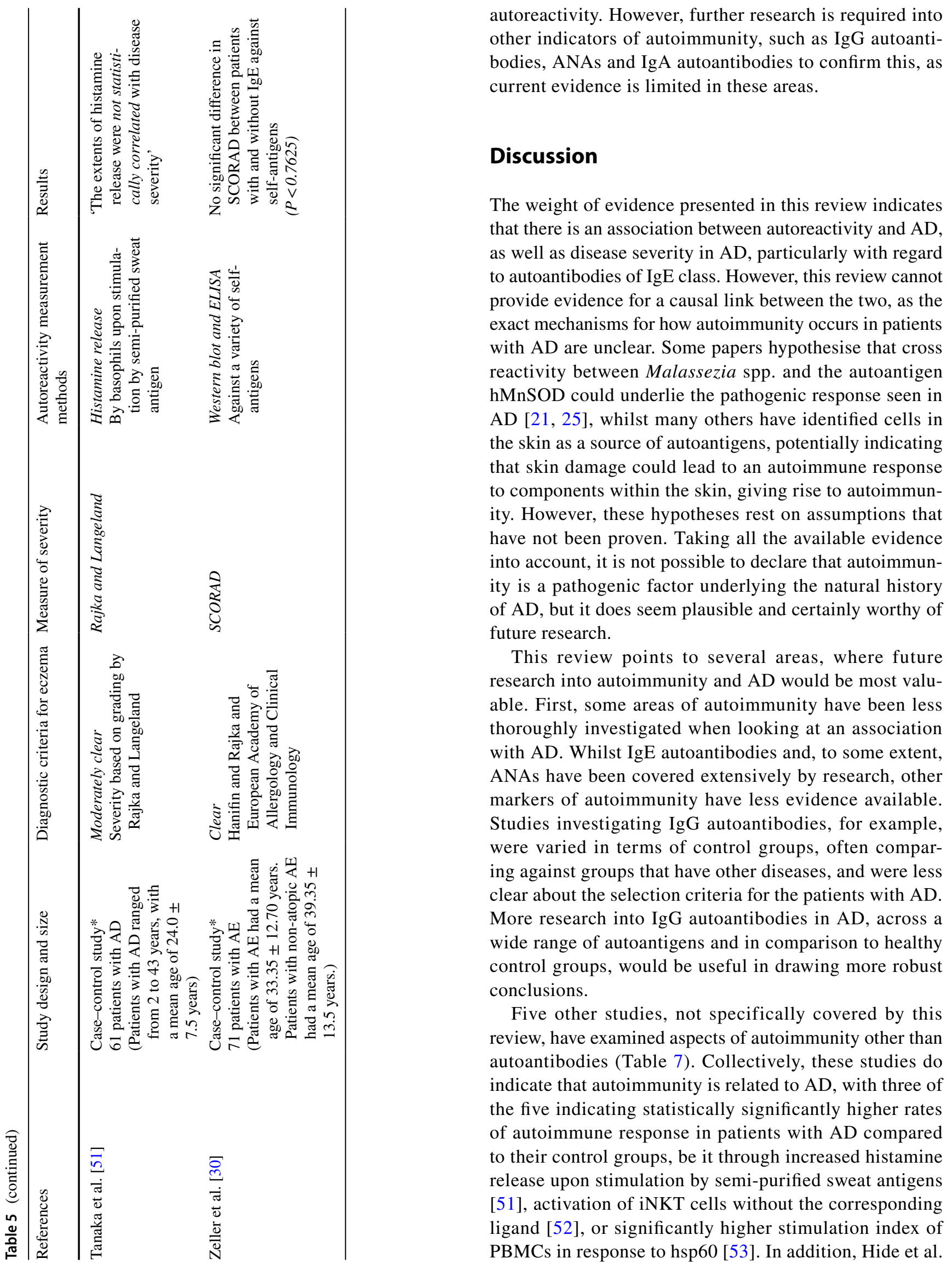


Table 6 Association of autoantibodies with severity of atopic dermatitis

\begin{tabular}{|c|c|c|}
\hline Marker of autoimmunity & $\begin{array}{l}\text { Papers that indicate a link between } \\
\text { AD disease severity and autoim- } \\
\text { munity }\end{array}$ & $\begin{array}{l}\text { Papers that do not indicate a link } \\
\text { between AD disease severity and auto- } \\
\text { immunity }\end{array}$ \\
\hline IgE autoantibodies & $\begin{array}{l}\mathbf{1 0} \\
\text { Altrichter et al. [18]* } \\
\text { Hiragun et al. [20]* } \\
\text { Ilves, Virolainen and Harvima [21]* } \\
\text { Kinaciyan et al. [48] } \\
\text { Kohsaka et al. [49]* } \\
\text { Lucae et al. [50] } \\
\text { Mittermann et al. [25]* } \\
\text { Mothes et al. [26]* } \\
\text { Natter et al. [27] } \\
\text { Schmid-Grendelmeier et al. [28]* }\end{array}$ & $\begin{array}{l}\mathbf{3} \\
\text { Hide et al. [47] } \\
\text { Tanaka et al. [51] }]^{\dagger} \\
\text { Zeller et al. }[30]^{\dagger}\end{array}$ \\
\hline ANAs & $\mathbf{0}$ & $\begin{array}{l}\mathbf{2} \\
\text { Higashi et al. [39] } \\
\text { Ress et al. }[43]^{\dagger}\end{array}$ \\
\hline Multiple indicators & $\mathbf{0}$ & $\begin{array}{l}\mathbf{1} \\
\text { Szakos et al., } 2004 \text { [34] }\end{array}$ \\
\hline
\end{tabular}

[47] show a greater frequency of response to intradermal injection of autologous sweat in AD patients, albeit without statistical analysis. The final study [54] does not seem to indicate an increased autoreactive $\mathrm{T}$-cell response in patients with $\mathrm{AD}$, but does indicate that there may be an alteration to the balance of CLA+/CLA - and CCR4+/ CCR4- cells. Overall, these less traditional indicators of autoimmunity show promising results in terms of a link with $\mathrm{AD}$, but further research is required to come to definitive conclusions.

There are also new indicators of autoimmunity that, whilst not meeting the inclusion criteria of this review, could provide insight into AD. Some interesting papers have investigated the function of regulatory $\mathrm{T}$ cells (Tregs) in AD with research indicating that the suppressive effect of Tregs on $\mathrm{CD}^{+} \mathrm{CLA}^{+} \mathrm{T}$-cell proliferation is inhibited in AD [55]. This would be a similar mechanism to other autoimmune/inflammatory diseases such as psoriasis, which shows impaired suppression of $\mathrm{CD} 4^{+} \mathrm{CD} 25^{-} \mathrm{T}$ cells [56]. Zhang et al. [55] note that further experiments are needed to address the theory that the $\mathrm{CD}^{+} \mathrm{CLA}^{+} \mathrm{T}$ cells in patients with $\mathrm{AD}$ might resist suppression, as opposed to there being dysregulation of Tregs, but further research into this field could provide a valuable insight into the mechanism behind autoimmunity. Later research corroborated this [57], with both papers suggesting that reduced inhibition of Teff cells could cause impaired self-tolerance in patients with AD, but further research would assist in elucidating specific mechanisms underlying the autoimmune response.

Another area that could provide useful research into autoimmunity and AD is analysis of genetic variants and potential associations with AD. For example, copy-number variations of the human histamine $\mathrm{H} 4$ receptor (HRH4) gene have been shown to be associated with AD [58], as well as a number of other autoimmune conditions such as SLE [59]. Whilst the exact mechanisms involved with the human histamine $\mathrm{H} 4$ receptor gene and AD are unclear, Chen et al. [58] suggest that the expression of HRH4 could be enhanced because of inflammatory stimuli found in autoimmune diseases, leading to a stronger response to histamine. This is an example of another potential component to the autoimmune pathogenesis in AD and is an area that warrants future research.

How autoimmunity is related to AD in animal models also warrants further research. Using animal models could lead to greater understanding of whether autoimmunity causes $\mathrm{AD}$, perpetuates $\mathrm{AD}$, or whether it is just an associated factor. Differences in ethical considerations for humans and animals allows for different studies to be carried out in animals, allowing more flexibility in study design and an ability to more easily identify causation.

Finally, further research into how different phenotypes of AD are associated with autoimmunity could provide a strong basis for future clinical research. Patients with AD can be divided into intrinsic and extrinsic categories, as well as other groups, including age of diagnosis and ethnic origin [60]. These groups have different disease characteristics, so more research into the underlying pathogenic mechanisms within these groups, be it related to autoimmunity or other factors, would be useful to aid understanding and potentially improve future treatments. 


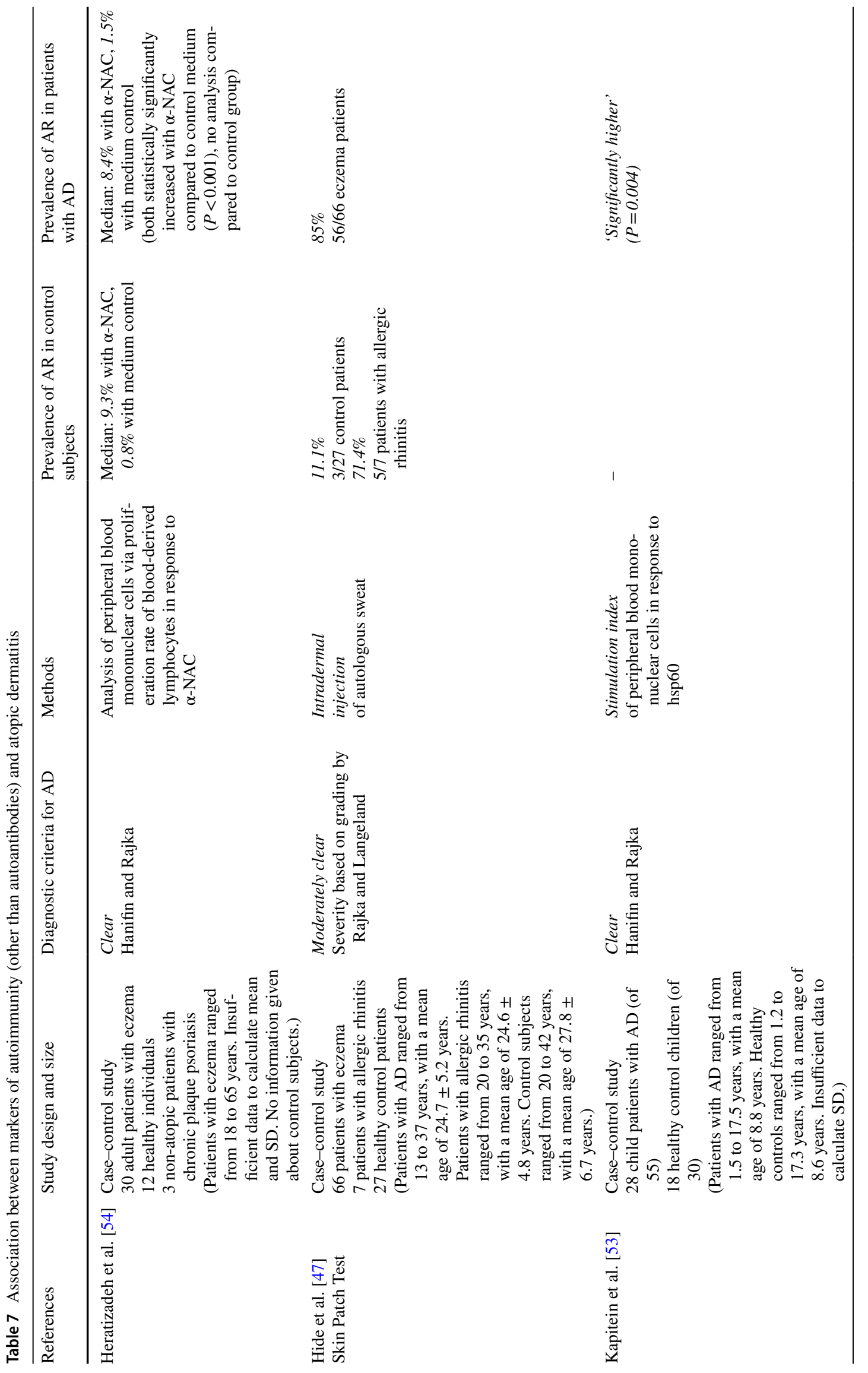




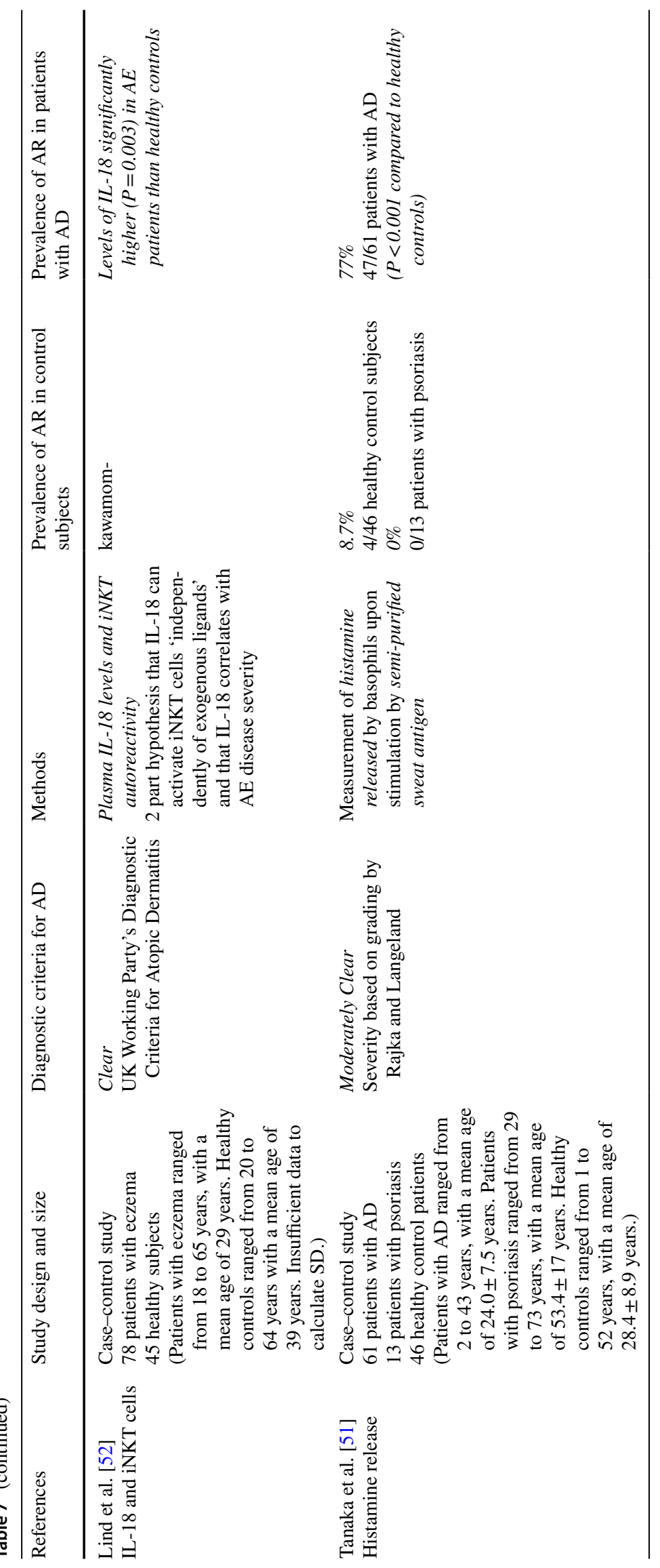


Funding There is no funding source.

\section{Compliance with ethical standards}

Conflict of interest The authors declare that they have no conflict of interest.

Ethical approval This article does not contain any studies with human participants or animals performed by any of the authors.

Open Access This article is distributed under the terms of the Creative Commons Attribution 4.0 International License (http://creativeco mmons.org/licenses/by/4.0/), which permits unrestricted use, distribution, and reproduction in any medium, provided you give appropriate credit to the original author(s) and the source, provide a link to the Creative Commons license, and indicate if changes were made.

\section{References}

1. Wise F, S M (1933) The 1933 year book of dermatology and syphilology. Year Book Publishers. Inc., Chicago

2. Darsow U, Eyerich K, Ring J (2014) Eczema, Atopic Eczema and Atopic Dermatitis. World Allergy Organisation. http://www. worldallergy.org/professional/allergic_diseases_center/atopi ceczema/. Accessed 26 October 2017

3. Williams H, Stewart A, von Mutius E, Cookson W, Anderson HR,, Three Study G (2008) International study of A, allergies in childhood phase $\mathrm{O}$. Is eczema really on the increase worldwide? J Allergy Clin Immunol 121:947-954

4. Odhiambo JA, Williams HC, Clayton TO, Robertson CF, Asher MI, Group IPTS (2009) Global variations in prevalence of eczema symptoms in children from ISAAC Phase Three. J Allergy Clin Immunol 124:1251-1258

5. Boguniewicz M, Leung DY (2011) Atopic dermatitis: a disease of altered skin barrier and immune dysregulation. Immunol Rev 242:233-246

6. Hong J, Buddenkotte J, Berger TG, Steinhoff M (2011) Management of itch in atopic dermatitis. Semin Cutan Med Surg 30:71-86

7. Flohr C, Johansson SG, Wahlgren CF, Williams H (2004) How atopic is atopic dermatitis? J Allergy Clin Immunol 114:150-158

8. Abeck D, Mempel M (1998) Staphylococcus aureus colonization in atopic dermatitis and its therapeutic implications. Br J Dermatol 139(Suppl 53):13-16

9. Travers JB (2014) Toxic interaction between Th2 cytokines and Staphylococcus aureus in atopic dermatitis. J Invest Dermatol 134:2069-2071

10. Andersen YM, Egeberg A, Gislason GH, Skov L, Thyssen JP (2017) Autoimmune diseases in adults with atopic dermatitis. J Am Acad Dermatol 76:274-280

11. Bieber T (2010) Atopic dermatitis. Ann Dermatol 22:125-137

12. Mount S (2014) Atopic Dermatitis Found To Be an ImmuneDriven Disease, News Releases. http://www.mountsinai.org/about -us/newsroom/press-releases/atopic-dermatitis-found-to-be-animmune-driven-disease. Accessed 28 October 2017

13. Beck LA, Thaci D, Hamilton JD, Graham NM, Bieber T, Rocklin R, Ming JE, Ren H, Kao R, Simpson E, Ardeleanu M, Weinstein SP, Pirozzi G, Guttman-Yassky E, Suarez-Farinas M, Hager MD, Stahl N, Yancopoulos GD, Radin AR (2014) Dupilumab treatment in adults with moderate-to-severe atopic dermatitis. N Engl J Med 371:130-139
14. Tang TS, Bieber T, Williams HC (2012) Does "autoreactivity" play a role in atopic dermatitis? J Allergy Clin Immunol 129:1209-1215

15. Moher D, Liberati A, Tetzlaff J, Altman DG, Group P (2009) Preferred reporting items for systematic reviews and meta-analyses: the PRISMA statement. BMJ 339:b2535

16. Du Toit G, Prescott R, Lawrence P, Johar A, Brown G, Weinberg EG, Motala C, Potter PC (2006) Autoantibodies to the high-affinity $\mathrm{IgE}$ receptor in children with chronic urticaria. Ann Allergy Asthma Immunol 96:341-344

17. Aichberger KJ, Mittermann I, Reininger R, Seiberler S, Swoboda I, Spitzauer S, Kopp T, Stingl G, Sperr WR, Valent P, Repa A, Bohle B, Kraft D, Valenta R (2005) Hom s 4, an IgE-reactive autoantigen belonging to a new subfamily of calcium-binding proteins, can induce Th cell type 1-mediated autoreactivity. J Immunol 175:1286-1294

18. Altrichter S, Kriehuber E, Moser J, Valenta R, Kopp T, Stingl G (2008) Serum IgE autoantibodies target keratinocytes in patients with atopic dermatitis. J Invest Dermatol 128:2232-2239

19. Guarneri F, Costa C, Foti C, Hansel K, Guarneri C, Guarneri B, Lisi P, Stingeni L (2015) Frequency of autoallergy to manganese superoxide dismutase in patients with atopic dermatitis: experience of three Italian dermatology centres. Br J Dermatol 173:559-562

20. Hiragun M, Hiragun T, Ishii K, Suzuki H, Tanaka A, Yanase Y, Mihara S, Haruta Y, Kohno N, Hide M (2014) Elevated serum IgE against MGL_1304 in patients with atopic dermatitis and cholinergic urticaria. Allergol Int 63:83-93

21. Ilves T, Virolainen A, Harvima IT (2016) Immediate wheal reactivity to autologous sweat in atopic dermatitis is associated with clinical severity, serum total and specific IgE and sweat tryptase activity. Int Arch Allergy Immunol 170:84-91

22. Kawamoto N, Yamada A, Ohkouchi S, Maeda T, Tanaka S, Hashimoto T, Saijo Y, Saijo S, Nukiwa T, Shichijo S, Aizawa H, Itoh K (2003) IgG reactive to CTL-directed epitopes of self-antigens is either lacking or unbalanced in atopic dermatitis patients. Tissue Antigens 61:352-361

23. Kortekangas-Savolainen O, Peltonen S, Pummi K, Kalimo K, Savolainen J (2004) IgE-binding components of cultured human keratinocytes in atopic eczema/dermatitis syndrome and their crossreactivity with Malassezia furfur. Allergy 59:168-173

24. Mittermann I, Reininger R, Zimmermann M, Gangl K, Reisinger J, Aichberger KJ, Greisenegger EK, Niederberger V, Seipelt J, Bohle B, Kopp T, Akdis CA, Spitzauer S, Valent P, Valenta R (2008) The IgE-reactive autoantigen Hom s 2 induces damage of respiratory epithelial cells and keratinocytes via induction of IFN-gamma. J Invest Dermatol 128:1451-1459

25. Mittermann I, Wikberg G, Johansson C, Lupinek C, Lundeberg L, Crameri R, Valenta R, Scheynius A (2016) IgE sensitization profiles differ between adult patients with severe and moderate atopic dermatitis. PLoS One 11:e0156077

26. Mothes N, Niggemann B, Jenneck C, Hagemann T, Weidinger S, Bieber T, Valenta R, Novak N (2005) The cradle of IgE autoreactivity in atopic eczema lies in early infancy. J Allergy Clin Immunol 116:706-709

27. Natter S, Seiberler S, Hufnagl P, Binder BR, Hirschl AM, Ring J, Abeck D, Schmidt T, Valent P, Valenta R (1998) Isolation of cDNA clones coding for IgE autoantigens with serum IgE from atopic dermatitis patients. FASEB J 12:1559-1569

28. Schmid-Grendelmeier P, Fluckiger S, Disch R, Trautmann A, Wuthrich B, Blaser K, Scheynius A, Crameri R (2005) IgEmediated and $\mathrm{T}$ cell-mediated autoimmunity against manganese superoxide dismutase in atopic dermatitis. J Allergy Clin Immunol 115:1068-1075

29. Valenta R, Maurer D, Steiner R, Seiberler S, Sperr WR, Valent P, Spitzauer S, Kapiotis S, Smolen J, Stingl G (1996) 
Immunoglobulin $\mathrm{E}$ response to human proteins in atopic patients. J Invest Dermatol 107:203-208

30. Zeller S, Rhyner C, Meyer N, Schmid-Grendelmeier P, Akdis CA, Crameri R (2009) Exploring the repertoire of IgE-binding selfantigens associated with atopic eczema. J Allergy Clin Immunol 124:278-285

31. Bergman R, Ramon M, Wildbaum G, Avitan-Hersh E, Mayer E, Shemer A, Karin N (2009) Psoriasis patients generate increased serum levels of autoantibodies to tumor necrosis factor-alpha and interferon-alpha. J Dermatol Sci 56:163-167

32. Neuber K, Mahnss B, Hubner C, Gergely H, Weichenthal M (2006) Autoantibodies against CD28 are associated with atopic diseases. Clin Exp Immunol 146:262-269

33. Ochs RL, Muro Y, Si Y, Ge H, Chan EK, Tan EM (2000) Autoantibodies to DFS $70 \mathrm{kd} /$ transcription coactivator p75 in atopic dermatitis and other conditions. J Allergy Clin Immunol 105:1211-1220

34. Szakos E, Lakos G, Aleksza M, Hunyadi J, Farkas M, Solyom E, Sipka S (2004) Relationship between skin bacterial colonization and the occurrence of allergen-specific and non-allergen-specific antibodies in sera of children with atopic eczema/dermatitis syndrome. Acta Derm Venereol 84:32-36

35. Ambrozic A, Avicin T, Ichikawa K, Kveder T, Matsuura E, Hojnik M, Atsumi T, Rozman B, Koike T (2002) Anti-beta(2)-glycoprotein I antibodies in children with atopic dermatitis. Int Immunol 14:823-830

36. El-Rachkidy RG, Young HS, Griffiths CE, Camp RD (2008) Humoral autoimmune responses to the squamous cell carcinoma antigen protein family in psoriasis. J Invest Dermatol 128:2219-2224

37. Ress K, Teesalu K, Annus T, Putnik U, Lepik K, Luts K, Uibo O, Uibo R (2014) Low prevalence of IgA anti-transglutaminase 1, 2 , and 3 autoantibodies in children with atopic dermatitis. BMC Res Notes 7:310

38. Dhar S, Kanwar AJ, Deodhar SD (1997) Lack of antinuclear antibody in children with atopic dermatitis. Indian J Dermatol Venereol Leprol 63:5-8

39. Higashi N, Niimi Y, Aoki M, Kawana S (2009) Clinical features of antinuclear antibody-positive patients with atopic dermatitis. $\mathbf{J}$ Nippon Med Sch 76:300-307

40. Ohkouchi K, Mizutani H, Tanaka M, Takahashi M, Nakashima K, Shimizu M (1999) Anti-elongation factor-1alpha autoantibody in adult atopic dermatitis patients. Int Immunol 11:1635-1640

41. Tada J, Toi Y, Yoshioka T, Fujiwara H, Arata J (1994) Antinuclear antibodies in patients with atopic dermatitis and severe facial lesions. Dermatology 189:38-40

42. Taniguchi Y, Yamakami A, Sakamoto T, Nakamura Y, Okada H, Tanaka H, Mizutani H, Shimizu M (1992) Positive antinuclear antibody in atopic dermatitis. Acta Derm Venereol Suppl (Stockh) 176:62-64

43. Ress K, Metskula K, Annus T, Putnik U, Lepik K, Luts K, Uibo O, Uibo R (2015) Antinuclear antibodies in atopic dermatitis: a cross-sectional study on 346 children. Int J Dermatol 54:24-28

44. Stalder JF, Taïeb A, Atherton DJ, Bieber P, Bonifazi E, Broberg A, Calza A, Coleman R, De Prost Y, Stalder JF, Gelmetti C, Cuannetti A, Harper J, Künz B, Lachapelle JM, Langeland T, Lever R, Oranje AP, Oueille-Roussel C, Revuz J et al (1993) Severity scoring of atopic dermatitis: the SCORAD index. Consensus report of the European task force on atopic dermatitis. Dermatology 186:23-31

45. Rajka G, Langeland T (1989) Grading of the severity of atopic dermatitis. Acta Derm Venereol Suppl (Stockh) 144:13-14

46. The Cochrane Community (2014) Review Manager (RevMan5). https://community.cochrane.org/help/tools-and-software/revma n-5. Accessed 26 October 2017
47. Hide M, Tanaka T, Yamamura Y, Koro O, Yamamoto S (2002) IgE-mediated hypersensitivity against human sweat antigen in patients with atopic dermatitis. Acta Derm Venereol 82:335-340

48. Kinaciyan T, Natter S, Kraft D, Stingl G, Valenta R (2002) IgE autoantibodies monitored in a patient with atopic dermatitis under cyclosporin A treatment reflect tissue damage. J Allergy Clin Immunol 109:717-719

49. Kohsaka T, Hiragun T, Ishii K, Hiragun M, Kamegashira A, Hide M (2018) Different hypersensitivities against homologous proteins of MGL_1304 in patients with atopic dermatitis. Allergol Int 67:103-108

50. Lucae S, Schmid-Grendelmeier P, Wuthrich B, Kraft D, Valenta R, Linhart B (2016) IgE responses to exogenous and endogenous allergens in atopic dermatitis patients under long-term systemic cyclosporine A treatment. Allergy 71:115-118

51. Tanaka A, Tanaka T, Suzuki H, Ishii K, Kameyoshi Y, Hide M (2006) Semi-purification of the immunoglobulin E-sweat antigen acting on mast cells and basophils in atopic dermatitis. Exp Dermatol 15:283-290

52. Lind SM, Kuylenstierna C, Moll M, Winqvist EDJ, Lundeberg O, Karlsson L, Johansson MA,MTL, Scheynius C, Sandberg A, Karlsson JK MC (2009) IL-18 skews the invariant NKT-cell population via autoreactive activation in atopic eczema. Eur J Immunol 39:2293-2301

53. Kapitein B, Aalberse JA, Klein MR, de Jager W, Hoekstra MO, Knol EF, Prakken BJ (2013) Recognition of self-heat shock protein 60 by $T$ cells from patients with atopic dermatitis. Cell Stress Chaperones 18:87-95

54. Heratizadeh A, Mittermann I, Balaji H, Wichmann K, Niebuhr M, Valenta R, Werfel T (2011) The role of T-cell reactivity towards the autoantigen alpha-NAC in atopic dermatitis. Br J Dermatol 164:316-324

55. Zhang BX, Lyu JC, Liu HB, Feng DQ, Zhang DC, Bi XJ, Duan ZW, Ding G (2015) Attenuation of peripheral regulatory T-cell suppression of skin-homing CD8(+)T cells in atopic dermatitis. Yonsei Med J 56:196-203

56. Sugiyama H, Gyulai R, Toichi E, Garaczi E, Shimada S, Stevens SR, McCormick TS, Cooper KD (2005) Dysfunctional blood and target tissue CD4 + CD25high regulatory $\mathrm{T}$ cells in psoriasis: mechanism underlying unrestrained pathogenic effector $\mathrm{T}$ cell proliferation. J Immunol 174:164-173

57. Zhang YY, Wang AX, Xu L, Shen N, Zhu J, Tu CX (2016) Characteristics of peripheral blood CD4 + CD25 + regulatory T cells and related cytokines in severe atopic dermatitis. Eur J Dermatol 26:240-246

58. Chen B, Ye T, Shao Y, Zhang J, Zhong Q, Hu X, Zhang W, Yu B (2013) Association between copy-number variations of the human histamine $\mathrm{H} 4$ receptor gene and atopic dermatitis in a Chinese population. Clin Exp Dermatol 38:295-300; quiz 300 - 291

59. Zhang M, Venable JD, Thurmond RL (2006) The histamine H4 receptor in autoimmune disease. Expert Opin Investig Drugs 15:1443-1452

60. Bieber T, D'Erme AM, Akdis CA, Traidl-Hoffmann C, Lauener R, Schappi G, Schmid-Grendelmeier P (2017) Clinical phenotypes and endophenotypes of atopic dermatitis: Where are we, and where should we go? J Allergy Clin Immunol 139:S58-S64

Publisher's Note Springer Nature remains neutral with regard to jurisdictional claims in published maps and institutional affiliations. 